\title{
Eosinophil-cationic protein - a novel liquid prognostic biomarker in melanoma
}

\author{
Annika Krückel, Alvaro Moreira*, Waltraud Fröhlich, Gerold Schuler and Lucie Heinzerling
}

\begin{abstract}
Background: The role of eosinophils in cancer is not yet completely understood, but patients with eosinophilia show a trend towards longer survival in several types of cancer, including melanoma. However, eosinophil count at initial diagnosis of metastatic melanoma does not predict survival. Since eosinophil cationic protein (ECP) mediates anticancer effects, such as tissue remodelling and cytotoxic activity, we investigated this marker as an early prognostic marker in metastatic melanoma.

Methods: Serum of 56 melanoma patients was collected at the time of diagnosis of metastatic disease. ECP levels as measured by ELISA were correlated with overall survival (OS) in patients before systemic therapy with immunotherapy or chemotherapy. Statistical analyses were performed using the Log-Rank (Mantel-Cox) test.

Results: The median OS for patients with high serum ECP above $12.2 \mathrm{ng} / \mathrm{ml}$ was 12 months $(n=39)$, compared to 28 months for patients with ECP below this threshold ( $n=17 ; p=0.0642)$. In patients with cutaneous melanoma, excluding patients with uveal and mucosal melanoma, the survival difference was even more striking $(p=0.0393)$. ECP's effect size on OS was observed independently of the consecutive therapy. ECP levels were not correlated with LDH levels.

Conclusion: ECP seems to be a novel prognostic serum marker for the outcome of melanoma patients, which is independent of LDH and easy to perform in clinical practice. The striking negative prognostic value of high ECP level is unanticipated and can guide patient management.
\end{abstract}

Keywords: Eosinophil cationic protein (ECP), Melanoma, Biomarker, Prognosis, Eosinophils

\section{Background}

Established prognostic markers in melanoma - besides TNM stage - include LDH (lactate dehydrogenase) and performance status $[1,2]$ while the tumour markers S100 B protein and protein melanoma-inhibitory-activity (MIA) are mostly used to detect progression of disease but do not correlate directly with prognosis $[3,4]$.

Several studies have shown that eosinophil levels are linked with prognosis in different tumour entities [5-7]. Increased frequencies of eosinophils were described to predict a better outcome in primary small cell oesophageal carcinoma and gastrointestinal, colorectal, breast and prostate cancer $[5,8,9]$. However, patients with eosinophilia show a worse prognosis in other

\footnotetext{
* Correspondence: alvaro.moreira@uk-erlangen.de; Lucie.Heinzerling@ukerlangen.de

Department of Dermatology, University Hospital Erlangen,

Friedrich-Alexander-University Erlangen-Nürnberg (FAU), 91054 Erlangen, Germany
}

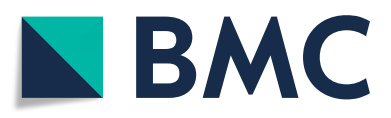

(c) The Author(s). 2019 Open Access This article is distributed under the terms of the Creative Commons Attribution 4.0 International License (http://creativecommons.org/licenses/by/4.0/), which permits unrestricted use, distribution, and

reproduction in any medium, provided you give appropriate credit to the original author(s) and the source, provide a link to the Creative Commons license, and indicate if changes were made. The Creative Commons Public Domain Dedication waiver (http://creativecommons.org/publicdomain/zero/1.0/) applies to the data made available in this article, unless otherwise stated. tumour entities such as Hodgkin's lymphoma, oral squamous cell carcinoma or cervical carcinoma [5, 6, 9-12]. Due to these inconsistent findings the role of eosinophils in tumour control is still not fully understood $[7,9,13]$.

Eosinophil count has already been shown to be a predictive biomarker for therapy with immune checkpoint inhibitors in melanoma [14]. Baseline frequencies as well as an increase of the number of eosinophils between the first and the second infusion of the anti-CTLA-4 antibody ipilimumab correlate with a better overall survival (OS) [14-16]. Regarding therapy with anti-PD-1 antibodies, eosinophil count at baseline also correlated with OS of melanoma patients [14, 17]. Additionally, recent studies by our research group revealed the prognostic value of eosinophils in melanoma patients [9]. A prolonged survival was demonstrated in both cohorts of melanoma patients with eosinophilia, immunotherapy-naive and in patients receiving immunotherapy [9]. However, in 
most cases patients only developed eosinophilia during the course of metastatic disease, thus eosinophil count at initial diagnosis of metastatic disease did not predict survival $[9,18]$.

Murine studies indicate that eosinophils are involved in $\mathrm{CD}^{+} \mathrm{T}$ cell-mediated tumour rejection by producing chemoattractants, such as CCL5, CXCL9 and CXCL10 [19]. Furthermore, studies on cancer patients also suggest that eosinophilic granulocytes affect tumour cells directly through the secretion of cytotoxic proteins [7, 19].

Eosinophil-derived neurotoxin (EDN), for example, is associated with intratumoural cell apoptosis [7], but the role of other eosinophilic cytotoxins, like eosinophil cationic protein $(\mathrm{ECP})$, eosinophil peroxidase $(\mathrm{EPO})$ or major basic protein (MBP) is not clear yet $[7,20]$.

ECP serves as a ribonuclease and belongs to RNase A family 3 [7, 12]. Its release can be induced by immunoglobulins (IgE, IgG), surface-bound complement as well as lipid mediators (lipopolysaccharides (LPS) or Lipid A) [7, 12, 21]. Though ECP's ribonucleolytic activity is low, its cell membrane binding mediates a multitude of further functions, like osmotic lysis, synthesis of reactive oxygen species, reversed membrane asymmetry, chromatin condensation as well as increased Caspase-3-like activity and, thus, cytotoxicity as shown in mammalian cell culture models [22]. It was suggested that ECP might, aside from harming various microorganisms $[7,12,22$, 23], also have cytotoxic activity against cancer cells, such as Hodgkin lymphoma and colorectal tumor cells [7, 12, 24-26], however, its definite role in human cancer is yet to be investigated. In studies on oral squamous carcinoma cell lines, ECP did not just limit cell survival, but induced morphological transformation, including vacuolation, formation of blebs and disabled cell adhesion [24]. On the contrary, ECP was suggested to promote tumour infiltration through muscle fiber corrosion [7]. According to in vitro experiments, ECP was involved in degradation of membrane-associated cytoskeletal proteins and myofibrillar proteins, such as myosin heavy chain as well as $\alpha$-actin [7]. Moreover, in vitro studies showed that ECP inhibits immune functions such as the production of immunoglobulins as well as $\mathrm{T}$ cell proliferation $[7,27]$. However, the role of ECP in vivo has to be determined.

This study investigates whether serum levels of ECP have a prognostic value for patients with metastatic melanoma.

\section{Methods}

\section{Patients and clinical characteristics}

In total, 56 patients with metastatic melanoma treated in our clinic from January 2004 to September 2017 were included in this study and analysed retrospectively. Variables that were analysed include gender, age, tumour involvement, type of melanoma, systemic therapies, and overall survival. The patient cohort incorporated patients independently of their subsequent therapy. The patient characteristics are depicted in Table 1 , with $p$-values included. The cohort included all histological types of melanoma (cutaneous melanoma, mucosal melanoma, uveal melanoma and melanoma of unknown primary). Due to biological differences between mucosal/uveal and cutaneous melanoma, overall survival (OS) of patients with cutaneous melanoma was analysed separately. Melanoma of unknown primary (MUP) was subsumed under cutaneous melanoma. Blood sera routinely assessed for tumour markers were used for analysis of eosinophil cationic protein (ECP). This retrospective study was exempt from full application to the Ethics Committee, University of Erlangen.

\section{Determination of ECP in serum}

For determination of ECP blood sera stored at $-20^{\circ} \mathrm{C}$ were thawed and measured by enzyme-linked immunosorbent assay ELISA (Cusabio \#CSB-E11729h) with a detection range of $1.56-100 \mathrm{ng} / \mathrm{ml}$ according to manufacturer's protocol. Sera from the time at initial diagnosis of metastatic melanoma were taken defining the initial diagnosis as $0-6$ months from the date of stage IV diagnosis. Duplicates of each sample were measured. Serum levels of at least $16.0 \mathrm{ng} / \mathrm{ml}$ were defined as elevated, because healthy individuals have a $95 \%$ range from $2.3-15.9 \mathrm{ng} / \mathrm{ml}$ in the serum [28]. Additionally, a cut-off of $12.2 \mathrm{ng} / \mathrm{ml}$, as determined by recursive partitioning, was analysed and correlated with survival.

\section{Determination of LDH and blood counts}

Serum lactate dehydrogenase (LDH) and blood counts were routinely measured in our lab. LDH was analysed by means of the LDH-ratio (actual value divided by the upper limit of normal). Eosinophilia was defined as at least $5 \%$ eosinophils in peripheral blood counts.

In 4 of 56 cases eosinophil counts were not analysed at the time of serum assessment. In these patients the eosinophil counts closest to the serum assessment was taken i.e. a maximum of 4 months before or after.

\section{Statistical methods}

Event-time distributions were estimated with the Kaplan-Meier method. Log-Rank (Mantel-Cox) test was performed to determine the $p$-value. Cut-off values were determined with recursive partitioning. For contingency analyses Chi-square test and Fisher's exact test were utilised. Mann-Whitney test was used for nonparametric tests. Univariate and multivariate analysis were performed with Cox proportional hazard models. Graphing was created using GraphPad Prism and R. 
Table 1 Patient characteristics

\begin{tabular}{|c|c|c|c|c|c|c|}
\hline \multicolumn{2}{|l|}{ Variables } & \multirow{2}{*}{\multicolumn{2}{|c|}{$\begin{array}{l}\text { Patients with ECP high }{ }^{\mathrm{a}}(n=34) \\
60 \text { years ( } 40-83 \text { years) }\end{array}$}} & \multirow{2}{*}{\multicolumn{2}{|c|}{$\begin{array}{l}\text { Patients with ECP low }{ }^{\mathrm{b}}(n=22) \\
64 \text { years }(31-90 \text { years })\end{array}$}} & \multirow{2}{*}{$\frac{p \text {-value }}{0.3877}$} \\
\hline Age & Median (Range) & & & & & \\
\hline \multirow[t]{2}{*}{ OS } & \multirow[t]{2}{*}{ Median (Range) } & \multicolumn{2}{|c|}{12 months (2-48 months) } & \multicolumn{2}{|c|}{28 months (3-44 months) } & 0.0916 \\
\hline & & $\mathrm{n}$ & $\%$ & $\mathrm{n}$ & $\%$ & \\
\hline \multirow[t]{2}{*}{ Gender } & Male & 22 & 65 & 14 & 64 & 0.9350 \\
\hline & Female & 12 & 35 & 8 & 36 & \\
\hline \multirow[t]{6}{*}{ Therapy } & Surgery & 31 & 91 & 19 & 86 & 0.6701 \\
\hline & Interferon-alpha & 13 & 38 & 7 & 32 & 0.6245 \\
\hline & Chemotherapy & 29 & 85 & 13 & 59 & 0.0270 \\
\hline & Radiotherapy & 25 & 74 & 17 & 77 & 0.7520 \\
\hline & Signal transduction inhibitor (targeted therapy) & 21 & 62 & 9 & 41 & 0.1264 \\
\hline & Checkpoint inhibitor therapy (immunotherapy) & 9 & 26 & 18 & 82 & $<0.0001$ \\
\hline \multirow[t]{4}{*}{ Type of melanoma } & Cutaneous & $20^{c}$ & 59 & 12 & 55 & 0.7520 \\
\hline & MUP & 5 & 15 & 9 & 41 & 0.0270 \\
\hline & Uveal & 3 & 9 & 1 & 5 & $>0.9999$ \\
\hline & Mucosal & $7^{c}$ & 21 & 0 & 0 & 0.0349 \\
\hline \multirow[t]{2}{*}{ LDH } & $>$ ULN & 20 & 59 & 18 & 82 & 0.0868 \\
\hline & $<U L N$ & 14 & 41 & 4 & 18 & \\
\hline \multirow[t]{2}{*}{ BRAF status $^{d}$} & V600 mutation & 13 & 38 & $9^{e}$ & 41 & 0.7151 \\
\hline & V600 wildtype & 14 & 41 & $12^{e}$ & 55 & \\
\hline \multicolumn{2}{|c|}{ Brain metastases (M1d) } & 18 & 53 & 8 & 36 & 0.2244 \\
\hline
\end{tabular}

defined as $>16.0 \mathrm{ng} / \mathrm{ml}$

${ }^{\mathrm{b}}$ defined as $<16.0 \mathrm{ng} / \mathrm{ml}$

cone patient has both, cutaneous and mucosal melanoma

${ }^{d}$ BRAF status of 7 patients was not tested, BRAF test result of one patient was not evaluable

ene patient has discrepant test results of two distinct metastases one with V600E mutation and one with wildtype

\section{Results}

\section{ECP is inversely correlated with survival}

Patients with low ECP at initial diagnosis of metastatic disease had a longer survival in comparison with patients with high ECP. With a cut-off at $16.0 \mathrm{ng} / \mathrm{ml}$ serum ECP, the median OS for patients with ECP levels of at least $16.0 \mathrm{ng} / \mathrm{ml}(n=34)$ was 12 months, compared with 28 months for patients with levels below this threshold $(n=22 ; p=0.0916$; Fig. 1a). A cut-off value of $16.0 \mathrm{ng} / \mathrm{ml}$ was used since $95 \%$ of healthy individuals have ECP values in the range from $2.3-15.9 \mathrm{ng} / \mathrm{ml}$ in the serum [28]. Dichotomizing at $12.2 \mathrm{ng} / \mathrm{ml}$, patients with higher serum levels $(n=39)$ had a median OS of 12 months, compared with 28 months for patients below this threshold ( $n=17 ; p=0.0642$; Fig. $1 \mathrm{~b})$. In a subsequent analysis the subgroup of uveal/mucosal melanoma with their different biology was excluded. The remaining patients with cutaneous melanoma $(n=45)$ were analysed separately. Using a cut-off of $16.0 \mathrm{ng} / \mathrm{ml}$, patients with elevated ECP levels $(n=24)$ had a median OS of 12 months, compared with 28 months for patients below this threshold ( $n=21 ; p=0.0597$; Fig. 2a). Dichotomizing at $12.2 \mathrm{ng} / \mathrm{ml}$, patients with lower ECP levels $(n=16)$ showed a statistically significant longer OS (median OS not reached) than patients with higher ECP levels (median OS 12 months; $n=29 ; p=0.0393$; Fig. 2b). Uveal and mucosal melanoma patients were not analysed separately due to the small number of subjects, with 4 and 7 cases, respectively. Interestingly, 3 out of 4 uveal melanoma patients and all mucosal melanoma patients $(7 / 7)$ were ECP high (cut-off: $16.0 \mathrm{ng} / \mathrm{ml}$ ).

\section{ECP and eosinophilia}

In order to investigate whether occurrence of eosinophilia (defined as at least $5 \%$ eosinophils in peripheral blood) was linked to presence of ECP, eosinophil counts in the course of the metastatic disease were analysed and compared to ECP serum levels. From the patients with decreased ECP serum levels (defined as $<16.0 \mathrm{ng} /$ $\mathrm{ml}, n=22)$ at diagnosis of metastatic disease, only $9 \%(n$ $=2$ ) had eosinophilia at that time. Regarding the patients with increased ECP levels $(n=34)$, eosinophilia was also present in only $15 \%(n=5)$ of the patients. Within the patients with initially increased ECP levels, 47\% (16/34) had at some point during the course of their disease an eosinophilia, whereas $32 \%(7 / 22)$ of the patients with decreased ECP also experienced one. In 4 of these 7 patients, blood sera at time of occurrence of eosinophilia 
A Overall survival of patients with metastatic melanoma (cut-off $16.0 \mathrm{ng} / \mathrm{ml}$ )

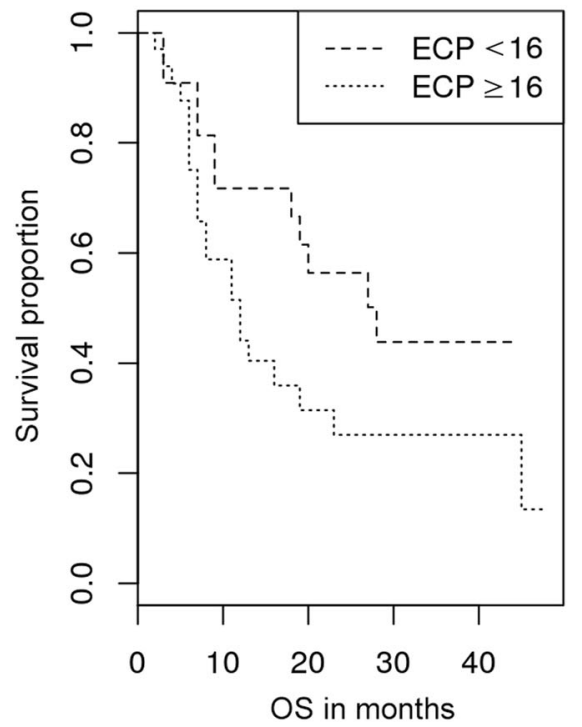

\section{B Overall survival of patients with} metastatic melanoma (cut-off $12.2 \mathrm{ng} / \mathrm{ml}$ )

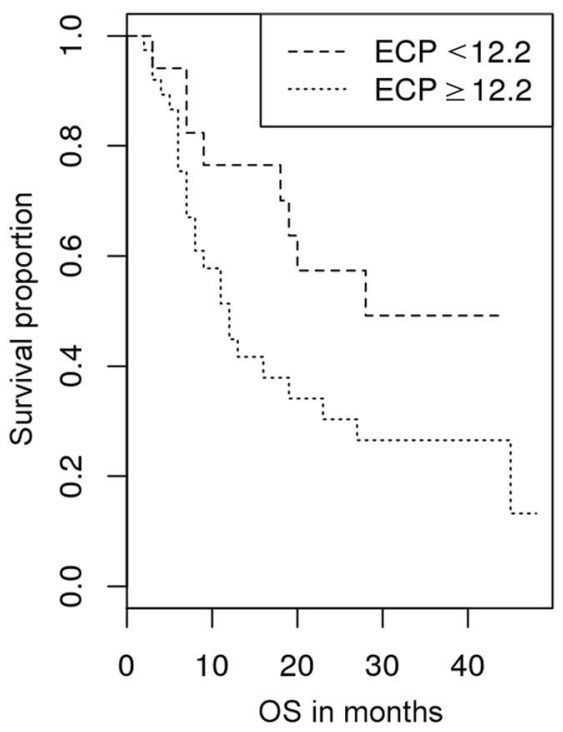

Fig. 1 a Overall survival of patients with metastatic melanoma (cut-off $16.0 \mathrm{ng} / \mathrm{ml})$. Overall survival of melanoma patients depending on ECP level $(n=56)$. Patients with an ECP level of $16.0 \mathrm{ng} / \mathrm{ml}$ or greater $(n=34)$ lived shorter (median OS $=12$ months) than patients with less than $16.0 \mathrm{ng} / \mathrm{ml}$ serum ECP ( $n=22$; median OS $=28$ months; $p=0.0916)$ at the time of metastatic disease (stage 4). $\mathbf{b}$ Overall survival of patients with metastatic melanoma (cut-off $12.2 \mathrm{ng} / \mathrm{ml}$ ). Overall survival of patients with an ECP level of $12.2 \mathrm{ng} / \mathrm{ml}$ or greater ( $n=39$; median OS $=12$ months) and of patients with less than $12.2 \mathrm{ng} / \mathrm{ml}$ serum ECP ( $n=17$; median $\mathrm{OS}=28$ months) at the time of stage 4 diagnosis within all melanoma patients $(n=56 ; p=0.0642)$
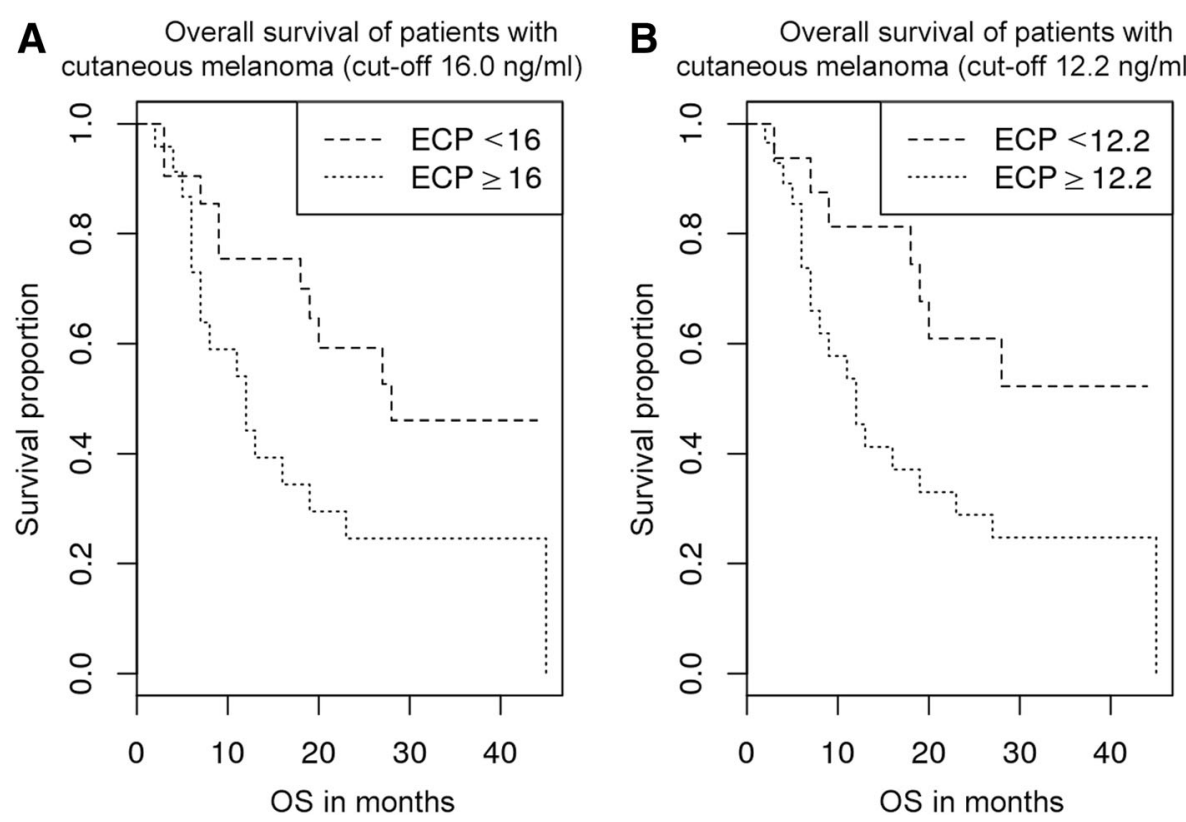

Fig. 2 a Overall survival of patients with cutaneous melanoma (cut-off $16.0 \mathrm{ng} / \mathrm{ml}$ ). Overall survival of patients with cutaneous melanoma depending on ECP level $(n=45)$. Patients with an ECP level of $16.0 \mathrm{ng} / \mathrm{ml}$ or greater $(n=24)$ lived shorter (median OS $=12$ months) than patients with less than $16.0 \mathrm{ng} / \mathrm{ml}$ serum ECP $(n=21$; median OS $=28$ months; $p=0.0597)$ at the time of metastatic disease (stage 4). b Overall survival of patients with cutaneous melanoma (cut-off $12.2 \mathrm{ng} / \mathrm{ml}$ ). Overall survival of patients with an ECP level of $12.2 \mathrm{ng} / \mathrm{ml}$ or greater ( $n=29$; median OS $=12$ months $)$ and of patients with less than $12.2 \mathrm{ng} / \mathrm{ml}$ serum ECP $(n=16$; median OS not reached) at the time of stage 4 diagnosis within patients having cutaneous melanoma $(n=45)$. The difference is statistically significant at $p=0.0393$ 
could be analysed as well. Interestingly, 75\% (3/4) of them still had decreased ECP levels when eosinophilia peak was reached (average ECP value $=6.1 \mathrm{ng} / \mathrm{ml}$ ). Only in one patient, ECP serum levels exceeded the cut-off (defined as $16.0 \mathrm{ng} / \mathrm{ml}$ ), but still remained lower $(35.7$ $\mathrm{ng} / \mathrm{ml}$ ) than the average value of ECP levels of the patients with increased levels at diagnosis of metastatic disease $(46.8 \mathrm{ng} / \mathrm{ml}, n=34)$.

Regarding development of eosinophilia after ECP assessment, no significant difference $(p=0.2824)$ could be found between patients with decreased ECP values and patients with increased ECP values.

\section{ECP is independent of LDH}

In order to investigate the role of ECP as an independent biomarker, we compared its serum levels in all patients of our cohort with serum lactate dehydrogenase (LDH) values, also taken at initial diagnosis of metastatic disease. As our statistical analysis shows, serum levels of ECP are independent of serum lactate dehydrogenase (Additional file 1). Coefficient of determination r2 was 0.026 , meaning only $2.6 \%$ of the variation on ECP levels can be explained by variations of LDH levels.

\section{Treatments of the cohort}

Subgroups of ECP low and ECP high were balanced with respect to age and gender. Treatments of the two cohorts were comparable (radiotherapy, surgery, interferon-alpha) whereas differences were found in the frequency of chemotherapy, immunotherapy and signal transduction therapy (Table 1).

\section{ECP as an independent prognostic biomarker}

In order to identify potentially confounding variables, Cox proportional hazard models were used for univariate and multivariate analysis. Age and gender had no influence on effect (Table 2). High ECP (cut-off: $16 \mathrm{ng} /$ $\mathrm{ml}$ ) increases the risk for a death, whereas targeted therapy as well as immunotherapy decrease this risk. The effect size of the influence of high ECP on survival is diminished by subsequent treatment with targeted or immunotherapy, but remains above 1 across all models and thus represents a marker for a decrease of OS.

\section{Discussion}

This study suggests that ECP represents an independent novel prognostic biomarker in patients with metastatic melanoma. Patients with higher ECP levels at the time of diagnosis of metastatic disease have a shorter survival compared to patients with lower ECP serum levels. Remarkably, survival difference was even more distinct in the subgroup of patients with cutaneous melanoma or MUP, excluding uveal and mucosal melanoma with their different biology. Furthermore, nearly all patients with uveal and mucosal melanoma showed elevated ECP levels.

Interestingly, ECP was associated with a worse outcome although it is secreted by eosinophils [7] whose presence is positively correlated with OS in melanoma [9]. This reverse correlation with survival was observed irrespective of the kind of therapy the patients were receiving and irrespective of the presence of eosinophilia. ECP's reported cytotoxicity against cancer cells in vitro $[7,12,24-26]$ thus does not correspond to its disadvantageous role in melanoma patients in vivo. Only Pereira et al. hypothesized that ECP might promote tumour progression by supporting tumour infiltration of human muscle tissue [7]. Given this unexpected finding of correlation of ECP high with poorer survival further studies in in vitro models and patient cohorts are required to characterize the role of ECP.

Table 2 Adjusting for gender, age, targeted and immunotherapy (multivariate analysis)

\begin{tabular}{lllll}
\hline & $(1)$ & $(2)$ & $(3)$ & $(4)$ \\
\hline ECP $>16$ & $1.869^{*}(0.893,3.913)$ & $1.869^{*}(0.893,3.913)$ & $1.873^{*}(0.895,3.918)$ & $1.300(0.578,2.922)$ \\
gender & & $0.999(0.482,2.074)$ & $0.987(0.475,2.053)$ & $0.692(0.311,1.538)$ \\
age & & & $1.006(0.977,1.035)$ & $1.008(0.978,1.039)$ \\
Targeted therapy & & & $0.728(0.318,1.663)$ \\
Immunotherapy & 56 & 56 & 56 & $0.327^{* *}(0.130,0.826)$ \\
Observations & 0.050 & 0.050 & 0.053 & 56 \\
$R^{2}$ & 0.982 & 0.982 & 0.982 & 0.146 \\
Max. Possible R & -110.967 & -110.967 & -110.893 & 0.982 \\
Log Likelihood & $2.760^{*}(\mathrm{df}=1)$ & $2.760(\mathrm{df}=2)$ & $2.900(\mathrm{df}=3)$ & -107.992 \\
Wald Test & $2.894^{*}(\mathrm{df}=1)$ & $2.894(\mathrm{df}=2)$ & $3.044(\mathrm{df}=3)$ & $7.910(\mathrm{df}=5)$ \\
LR Test & $2.841^{*}(\mathrm{df}=1)$ & $2.841(\mathrm{df}=2)$ & $2.985(\mathrm{df}=3)$ & $8.846(\mathrm{df}=5)$ \\
Score (Logrank) Test & & & $8.503(\mathrm{df}=5)$ \\
\hline
\end{tabular}

Note: ${ }^{*} p<0.1 ;{ }^{* *} p<0.05$ 
Since ECP is a granule cytotoxic protein of eosinophils [7], we would have assumed that eosinophilia precedes high ECP serum levels. However, this was not the case in our cohort. Only $15 \%$ of patients with elevated ECP show eosinophilia compared to $9 \%$ with low ECP. In the course of metastatic disease, $32 \%$ of patients with low ECP and $47 \%$ of patients with elevated ECP experienced eosinophilia. Thus, elevated levels of ECP are not directly associated with the presence of eosinophilia.

Furthermore, there was no correlation of ECP with LDH. Both, age and gender did not influence ECP's effect size on OS. Importantly, all ECP values were measured at diagnosis of stage IV metastatic disease. It is unclear why the ECP low group was subsequently treated with immunotherapy more often. They were however treated less often with targeted therapy. Targeted as well as immunotherapy, as life prolonging therapies, diminish ECP's effect size on OS, but high ECP levels still increase the risk of death when adjusting for those variables. Possibly, there is a latent variable that is connected to both, ECP and therapy, which has to be further investigated.

Although the function of ECP in cancer progression or rejection is still not fully understood, its levels were associated with prognosis in patients with metastatic melanoma. So ECP seems to represent a novel independent prognostic biomarker in melanoma and perhaps other tumours as well. The measurement of this liquid biomarker in routine clinical practice would be easy and time efficient. We are, therefore, currently validating $\mathrm{ECP}$ as a new biomarker.

\section{Conclusion}

Pretreatment ECP levels, collected at the time of diagnosis of stage IV metastatic disease, are associated with overall survival in melanoma patients. High serum ECP correlates with a poor prognosis, independently of the subsequent therapy.

ECP is a novel prognostic serum marker for the outcome of melanoma patients, which is independent of $\mathrm{LDH}$ and easy to perform in clinical practice. The negative prognostic value of high ECP level is unanticipated.

\section{Additional file}

Additional file 1: Correlation between pretreatment ECP and LDH levels. (PNG 26 kb)

\section{Abbreviations}

Anti-CTLA-4: Anti-cytotoxic t-lymphocyte-associated protein-4; Anti-PD1: Anti-programmed cell death-1; CCL5: C-C motif chemokine ligand 5; $\mathrm{CD}^{+}$: Cluster of differentiation $8^{+}$; CXCL10: C-X-C motif chemokine ligand 10; CXCL9: C-X-C motif chemokine ligand 9; ECP: Eosinophil cationic protein; EDN: Eosinophil-derived neurotoxin; ELISA: Enzyme-linked immunosorbent assay; EPO: Eosinophil peroxidase; Fig.: Figure; IgE: Immunoglobulin E; IgG: Immunoglobulin G; LDH: Lactate dehydrogenase;
LPS: Lipopolysaccharides; MBP: Major basic protein; MIA: Melanomainhibitory-activity; MUP: Melanoma of unknown primary; OS: Overall survival; TNM: Tumour, node, metastases

\section{Acknowledgements}

Annika Krückel performed the present work in fulfilment of the requirements of the Friedrich-Alexander-University Erlangen - Nürnberg (FAU) for obtaining the degree "Dr. med.". Susanne Bauer has contributed to the patient database.

\section{Funding}

Not applicable.

\section{Availability of data and materials}

The anonymized datasets used and/or analysed during the current study are available from the corresponding author on reasonable request.

\section{Authors' contributions}

All co-authors have read and approved the final version of the manuscript. AK, AM, LH contributed to writing the manuscript. AM and LH designed the clinical trial that GS oversaw. LH, AM conducted the clinical trial. WF performed the serum analyses. All co-authors contributed to analysing the data.

Ethics approval and consent to participate

Ethics approval for samples from the biobank was granted from the ethical committee FAU Erlangen-Nürnberg.

Consent for publication

Not applicable.

\section{Competing interests}

LH: Speaker fees, consultant, travel grant and advisory role: Bristol-Myers Squibb, MSD, Roche, GSK, Novartis, Amgen, Curevac, Sanofi, Pierre Fabre; Grants: Novartis.

AM has received honoraria from Roche. AK, WF, GS: Not applicable.

\section{Publisher's Note}

Springer Nature remains neutral with regard to jurisdictional claims in published maps and institutional affiliations.

Received: 23 June 2018 Accepted: 19 February 2019

Published online: 07 March 2019

\section{References}

1. Nikolin B, Djan I, Trifunovic J, Dugandzija T, Novkovic D, Djan V, Vucinic N. MIA, S100 and LDH as important predictors of overall survival of patients with stage IIb and IIc melanoma. J BUON 2016;21(3):691-697; PMID: 27569092.

2. Henry L, Fabre C, Guiraud I, Bastide S, Fabbro-Peray P, Martinez J, LavabreBertrand T, Meunier L, Stoebner PE. Clinical use of p-proteasome in discriminating metastatic melanoma patients: comparative study with LDH, MIA and S100B protein. Int J Cancer 2013;133(1):142-148; PMID:23238767; https://doi.org/10.1002/ijc.27991.

3. Li N, Mangini J, Bhawan J. New prognostic factors of cutaneous melanoma: a review of the literature. J Cutan Pathol 2002;29(6):324-340; PMID: 12135463

4. Utikal J, Schadendorf D, Ugurel S. Serologic and immunohistochemical prognostic biomarkers of cutaneous malignancies. Arch Dermatol Res 2007; 298(10):469-477; PMID:17221215.

5. Sakkal S, Miller S, Apostolopoulos V, Nurgali K. Eosinophils in cancer: favourable or unfavourable? Curr Med Chem 2016;23(7):650-666; PMID: 26785997.

6. Davis BP, Rothenberg ME. Eosinophils and Cancer. Cancer Immunol Res 2014;2(1):1 8; PMID:24778159; https://doi.org/10.1158/2326-6066.CIR-13-0196

7. Pereira MC, Oliveira DT, Kowalski LP. The role of eosinophils and eosinophil cationic protein in oral cancer: a review. Arch Oral Biol 2011;56(4):353-358; PMID:21112047.

8. Zhang Y, Ren H, Wang L, Ning Z, Zhuang Y, Gan J, Chen S, Zhou D, Zhu H, Tan $D$, et al. Clinical impact of tumor-infiltrating inflammatory cells in 
primary small cell esophageal carcinoma. Int J Mol Sci 2014;15(6):9718-9734; PMID: 24886814; doi:https://doi.org/10.3390/ijms15069718.

9. Moreira A, Leisgang W, Schuler G, Heinzerling L. Eosinophilic count as a biomarker for prognosis of melanoma patients and its importance in the response to immunotherapy. Immunotherapy. 2017;9(2):115-121; PMID: 28128709; https://doi.org/10.2217/imt-2016-0138.

10. von Wasielewski R, Seth S, Franklin J, Fischer R, Hübner K, Hansmann ML, Diehl V, Georgii A. Tissue eosinophilia correlates strongly with poor prognosis in nodular sclerosing Hodgkin's disease, allowing for known prognostic factors. Blood. 2000;95(4):1207-13 10666192.

11. Horiuchi K, Mishima K, Ohsawa M, Sugimura M, Aozasa K. Prognostic factors for well- differentiated squamous cell carcinoma in the oral cavity with emphasis on immunohistochemical evaluation. J Surg Oncol 1993;53(2):92-96; PMID:8501912; doi:https://doi.org/10.1002/jso.2930530209

12. Boix E, Torrent M, Sánchez D, Nogués MV. The antipathogen activities of eosinophil cationic protein. Curr. Pharm. Biotechnol. 2008;9:141-152; PMID: 18673279; doi:https://doi.org/10.2174/138920108784567353

13. Murdoch C, Muthana M, Coffelt SB, Lewis CE. The role of myeloid cells in the promotion of tumour angiogenesis. Nat Rev Cancer 2008;8(8):618-631; PMID:18633355.

14. Jacquelot N, Pitt JM, Enot DP, Roberti MP, Duong CPM, Rusakiewicz S, Eggermont AM, Zitvogel L. Immune biomarkers for prognosis and prediction of responses to immune checkpoint blockade in cutaneous melanoma. Oncoimmunology. 2017;6(8); PMID:28919986). https://doi.org/10. 1080/2162402X.2017.1299303.

15. Delyon J, Mateus C, Lefeuvre D, Lanoy E, Zitvogel L, Chaput N, Roy S, Eggermont $A M$, Routier $E$, Robert $C$. Experience in daily practice with ipilimumab for the treatment of patients with metastatic melanoma: an early increase in lymphocyte and eosinophil counts is associated with improved survival. Ann. Oncol. 2013;24(6):1697-1703; PMID:23439861; doi: https://doi.org/10.1093/annonc/mdt027

16. Ferrucci PF, Gandini S, Cocorocchio E, Pala L, Baldini F, Mosconi M, Antonini Cappellini GC, Albertazzi E, Martinoli C. Baseline relative eosinophil count as a predictive biomarker for ipilimumab treatment in advanced melanoma. Oncotarget. 2017;8(45):79809-79815; PMID:29108362; doi:https://doi.org/10. 18632/oncotarget.19748.

17. Weide B, Martens A, Hassel JC, Berking C, Postow MA, Bisschop K, Simeone E, Mangana J, Schilling B, Di Giacomo AM, et al. Baseline biomarkers for outcome of melanoma patients treated with pembrolizumab. Clin Cancer Res 2016;22(22):5487-5496; PMID:27185375; doi:https://doi.org/10.1158/ 1078-0432.CCR-16-0127.

18. Gross S, Erdmann M, Haendle I, Voland S, Berger T, Schultz E, Strasser E, Dankerl P, Janka R, Schliep S, et al. Twelve-year survival and immune correlates in dendritic cell vaccinated melanoma patients. JCI Insight 2017; 2(8); PMID:28422751; doi:https://doi.org/10.1172/ji.insight.91438.

19. Carretero R, Sektioglu IM, Garbi N, Salgado OC, Beckhove P, Hämmerling GJ. Eosinophils orchestrate cancer rejection by normalizing tumor vessels and enhancing infiltration of CD8+ T cells. Nat Immunol 2015;16(6):609-617; PMID:25915731; doi:https://doi.org/10.1038/ni.3159.

20. Molin D, Glimelius B, Sundström C, Venge P, Enblad G. The serum levels of eosinophil cationic protein (ECP) are related to the infiltration of eosinophils in the tumours of patients with Hodgkin's disease. Leuk Lymphoma 2001; 42(3):457-465; PMID:11699410; doi:https://doi.org/10.3109/

10428190109064602

21. Liu YS, Tsai PW, Wang Y, Fan TC, Hsieh CH, Chang MD, Pai TW, Huang CF, Lan CY, Chang HT. Chemoattraction of macrophages by secretory molecules derived from cells expressing the signal peptide of eosinophil cationic protein. BMC Syst Biol 2012;6:105; PMID:22906315; doi:https://doi. org/10.1186/1752-0509-6-105.

22. Navarro $S$, Aleu J, Jiménez M, Boix E, Cuchillo CM, Nogués M V. The cytotoxicity of eosinophil cationic protein/ribonuclease 3 on eukaryotic cell lines takes place through its aggregation on the cell membrane. Cell Mol Life Sci 2008;65(2):324-337; PMID:18087674; doi:https://doi.org/10.1007/ s00018-007-7499-7.

23. Venge P, Byström J. Eosinophil cationic protein (ECP). Int J Biochem Cell Biol 1998;30(4):433-437; PMID:9675876.

24. DE Lima PO, Dos Santos FV, Oliveira DT, DE Figueiredo RC, Pereira MC. Effect of eosinophil cationic protein on human oral squamous carcinoma cell viability. Mol Clin Oncol 2015;3(2):353-356; PMID: 25798266; doi:https:// doi.org/10.3892/mco.2014.477.
25. Legrand F, Driss V, Delbeke M, Loiseau S, Hermann E, Dombrowicz D, Capron M. Human eosinophils exert TNF- and Granzyme A-mediated Tumoricidal activity toward Colon carcinoma cells. J Immunol 2010;185(12): 7443-7451; PMID:21068403; doi:https://doi.org/10.4049/jimmunol.1000446.

26. Glimelius I, Rubin J, Fischer M, Molin D, Amini RM, Venge P, Enblad G. Effect of eosinophil cationic protein (ECP) on Hodgkin lymphoma cell lines. Exp Hematol 2011;39(8):850-858; PMID:21679745; doi:https://doi.org/10.1016/j. exphem.2011.05.006.

27. Venge P, Byström J, Carlson M, Hâkansson L, Karawacjzyk M, Peterson C, Sevéus $L$, Trulson A. Eosinophil cationic protein (ECP): molecular and biological properties and the use of ECP as a marker of eosinophil activation in disease. Clin Exp Allergy 1999;29(9):1172-1186; PMID:10469025.

28. Peterson CGB, Enander I, Nystrand J, Anderson AS, Nilsson L, Venge P. Radioimmunoassay of human eosinophil cationic protein (ECP) by an improved method. Establishment of normal levels in serum and turnover in vivo. Clin Exp Allergy 1991;21(5):561-567; PMID:1742647; doi:https://doi.org/ 10.1111/j.1365-2222.1991.tb00847.x.

\section{Ready to submit your research? Choose BMC and benefit from:}

- fast, convenient online submission

- thorough peer review by experienced researchers in your field

- rapid publication on acceptance

- support for research data, including large and complex data types

- gold Open Access which fosters wider collaboration and increased citations

- maximum visibility for your research: over $100 \mathrm{M}$ website views per year

At BMC, research is always in progress.

Learn more biomedcentral.com/submissions 